\title{
ENCONTRO E COMENSALIDADE NOS QUILOMBOS: O DEVIR QUILOMBO
}

\author{
Sonia Regina Lourenço ${ }^{1}$
}

Este artigo se propõe a explorar a possibilidade de pensar a comensalidade como uma prática de produção do parentesco em alguns contextos quilombolas. $\mathrm{O}$ texto programático de DaMatta, Segger \&Viveiros de Castro (1987) sobre a noção de pessoa ameríndia nas terras baixas da América do Sul, me fez pensar que a ideia de "comunidade de substância" ou "substancialidade" na fabricação de corpos poderá ser uma alternativa para compreender a ideia de socialidade quilombola pelas suas próprias perspectivas (GOW, 1991).

Algo se passa nos circuitos das festas de santo que remete à ideia de substâncias compartilhadas, comidas assadas e cozidas, rezas e cantos mobilizados e compartilhados pelos comensais: anfitriões, os festeiros donos das festas e dos assentamentos dos santos, e convidados. As comunidades quilombolas em Chapada dos Guimarães criaram um circuito de festas de irmandades de parentesco e a sua dobra, as irmandades de santo, que apresentam o pleno circuito das dádivas por onde transitam pessoas, palavras e coisas (MAUSS, 2003), prestações e contraprestações que reestabelecem e criam novas alianças. As anfitriãs, as festeiras donas das festas, devem propiciar comida e bebida em abundância para seus convidados, parentes e não parentes. Em cada festa de santo, a festeira cozinha e assa até seis novilhos ou bois. Quando não possui a quantidade de carne para sustentar a festa de três dias, as festeiras acionam relações de compadrio ou até mesmo provocam aqueles ou aquelas pessoas que estão em dívida com os santos para contribuir com quantidades significativas de carne e mandioca, os dois principais alimentos da culinária dos quilombos.

O parentesco, seguindo o conceito de Marshall Sahlins (2011) de relações de "mutualidade" integra e cria vínculos de reciprocidade que passam a ser quase uma obrigação para além da consequência de ser taxado como "pessoa boa" ou "pessoa ruim", que sabe partilhar seus bens com os outros, seus parentes. Os encontros para as festas de santo são uma forma que encontraram de "fazer parente". A teoria de Marshall Sahlins (2011) sobre a "mutualidade do ser" faz pensar que as relações de parentesco

\footnotetext{
${ }^{1}$ Universidade Federal de Mato Grosso, Brasil. Email: soniaufmt@gmail.com

ORCID id: https://orcid.org/0000-0002-0286-8917
}

Iluminuras, Porto Alegre, v. 20, n. 51, p. 298-322, dezembro, 2019. 
são marcadas por outras relações além da filiação, da descendência e do compadrio, tais como a alimentação, a procriação, a convivência, a memória, os vínculos com a terra e as experiências compartilhadas.

Além das substâncias e das memórias, as relações de parentesco implicam perigos como acusações de feitiçaria, as "porcariadas" como categorizam os quilombolas, e os mortos, as assombrações que aparecem para aterrorizar os vivos. Nesta perspectiva aberta por Sahlins, o estudo de Jane Carsten (2014: 106) mostra que o parentesco pode ter "gradações", "acumulações", "rupturas e dissoluções", envolvendo temas como "casas, adoção e fantasmas". Em outras palavras, e seguindo o argumento de Peter Gow (1991) de que a temporalidade e a historicidade podem estar codificadas no parentesco, e nos corpos. O parentesco como temporalidade, corporalidade e comensalidade parece configurar as relações nos quilombos Lagoinha de Cima, Morro do Cambambi e Itambé, quando aparecem vinculados ao tempo das irmandades e aos acontecimentos considerados mais importantes para eles, os parentes vivos e mortos. Quando contam as histórias e fatos acontecidos, falam de parentes, de intrigas e conflitos, de afetos e saudades.

Nos territórios quilombolas, a comida constitui a dimensão mais ampla da comensalidade, entendida como uma matriz relacional que conecta todos os seres, homens e mulheres, crianças e adultos, humanos e santos, humanos e animais, humanos e a terra, a memória e a ancestralidade. Estas relações envolvem práticas alimentares que transcendem os processos meramente físicos do ato de comer pois, o que se come, quando e com quem se come no mundo dos quilombos, implica acionar uma rede de relações de irmandades de santo e de parentesco, pondo em operação uma economia política de produção de pessoas e parentes.

A pesquisa etnográfica com as comunidades quilombolas na Amazônia Legal começou em 2012 no quilombo Lagoinha de Cima (Lourenço, 2015, 2016) e se estendeu para outros quilombos, Ribeirão Itambé e Morro do Cambambi, coletivos negros com contiguidade territorial e de parentesco entre si. As três comunidades de quilombos habitam territórios contíguos entre os rios Quilombo, rio Manso, rio da Casca, rio Acorá e rio Lagoinha, que atravessam e fazem divisas entre elas (ver Mapa 1), no sertão da zona rural do município de Chapada dos Guimarães, distante $60 \mathrm{~km}$ de Cuiabá, estado de Mato Grosso. Estas comunidades aguardam a regularização de seus territórios, desde que abriram os processos junto ao INCRA em 2005 para elaboração de laudos antropológicos com vistas a identificação e delimitação dos territórios 
quilombolas em conformidade com o artigo 68 do ADCT/CF-1988 e o Decreto $4.887 / 03^{2}$.

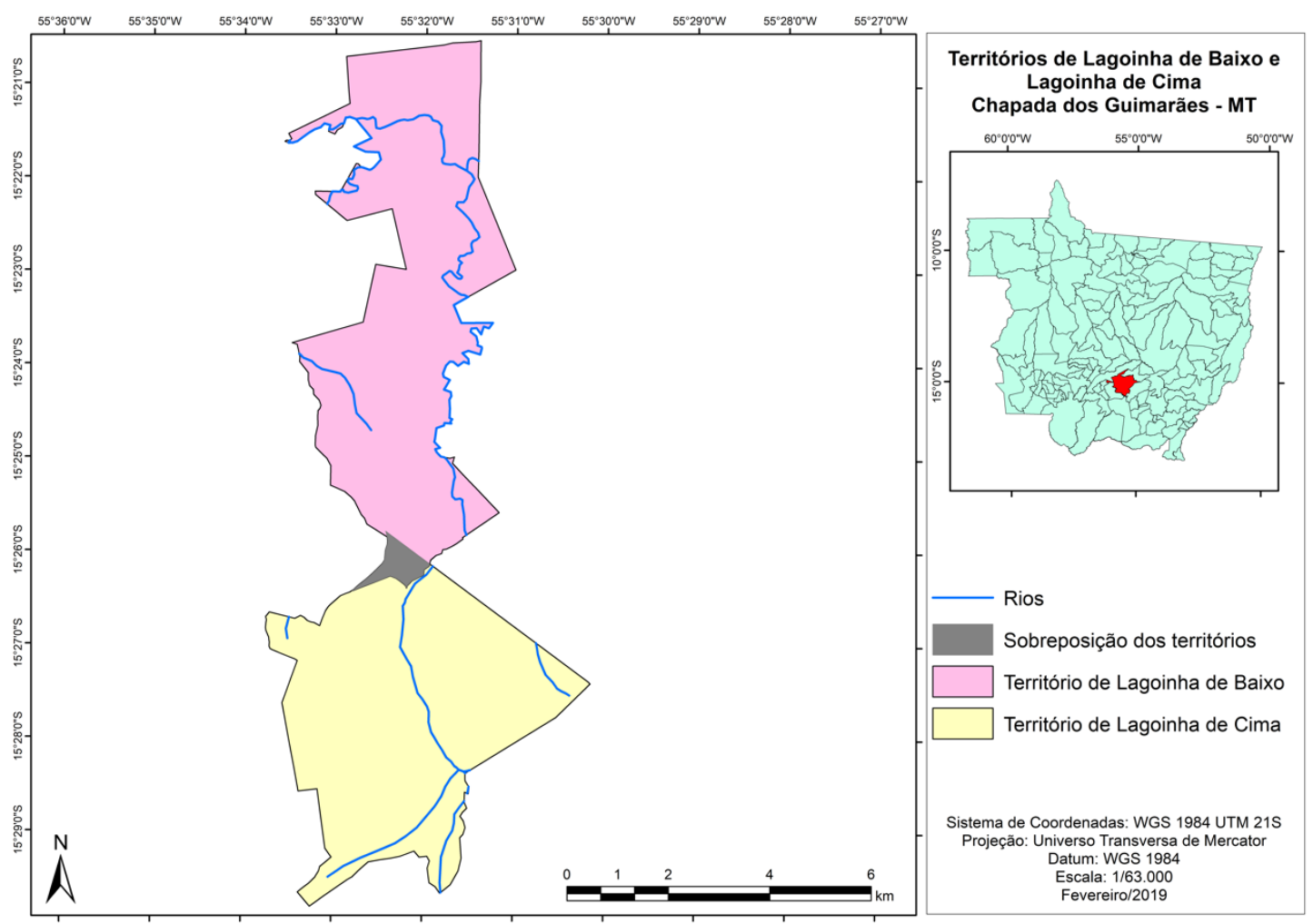

Mapa 1: Contiguidade e Sobreposição Territórios Quilombolas Lagoinha de Cima e Lagoinha de Baixo. Produção do mapa: Glaucia Ramirez Miranda (UFMT). ${ }^{3}$

A pesquisa de campo desenvolvida de 2012 a 2018, com períodos de maior e menor intensidade, registrou narrativas, entrevistas, genealogias de parentesco, realizou oficinas, acompanhou assembleias, festas de santo, produziu levantamento de dados socioeconômico e ambientais com vistas a produzir uma etnografia que descreva as formas contemporâneas de organização e arranjos sociais destes coletivos negros.

Os quilombos Lagoinha de Cima, Ribeirão Itambé e Morro do Cambambi se autoidentificam como "comunidades remanescentes de quilombos", categoria jurídica e política que vem sendo ressemantizada por eles durante o processo de identificação e delimitação para a regularização e titulação de seus territórios. As duas primeiras comunidades junto com Lagoinha de Baixo, abriram processo de reivindicação de seus

\footnotetext{
${ }^{2}$ Os laudos estão em processo de realização no âmbito do Termo de Execução Descentralizada firmado entre o INCRA e a UFMT em 17 de outubro de 2017 após 15 meses de idas e vindas do processo. O objeto do TED é a produção de três laudos antropológicos referentes às comunidades remanescentes de quilombos Lagoinha de Cima, Ribeirão Itambé e Morro do Cambambi.

${ }^{3}$ Glaucia Ramirez Miranda, professora e pesquisadora do Departamento de Solos e Engenharia Rural Faculdade de Agronomia, Medicina Veterinária e Zootecnia da UFMT integra a equipe técnica responsável pela produção de três Laudos Antropológicos para a identificação e delimitação dos territórios quilombolas de Lagoinha de Cima, Ribeirão Itambé e Morro do Cambambi.
} 
territórios no Instituto Nacional de Colonização e Reforma Agrária (INCRA) logo após receberem a certidão de reconhecimento de "comunidades remanescentes de quilombo" da Fundação Cultural Palmares em 2005. O quilombo de Cambambi recebeu a certidão em 2015 após as irmandades de Cachoeira Bom Jardim e Barro Preto Serra do Cambambi, já reconhecidas pela Fundação Cultural Palmares em 2005, decidirem se unir à Associação Remanescente de Quilombo Morro do Cambambi para "dar mais força" ao processo de reivindicação de direito à terra e por se autoidentificarem como descendentes de uma ancestralidade e ocupação histórica em comum.

A comunidade Lagoinha de Cima, organizada na Associação Quilombola Negra Rural, possui 15 residências dentro do exíguo território próximo à rodovia MT- 251, distante a $20 \mathrm{~km}$ da zona urbana do município de Chapada dos Guimarães. O quilombo está confinado entre plantações de soja, milho e algodão, monoculturas que fazem uso intensivo de agrotóxicos. As outras 36 famílias que compõem aproximadamente 210 pessoas da população do quilombo, residem nos bairros Pedregal, Novo Paraíso, Planalto e Pedra Noventa, no município de Cuiabá, e nos bairros São Sebastião e Olho d'Água, no município de Chapada dos Guimarães. Outras famílias residem em Planalto da Serra, estado de Mato Grosso e em Sorocaba, estado de São Paulo. Em Lagoinha de Cima, não há espaço para todas as famílias do quilombo construírem suas casas e cultivar suas roças, em suma, viver junto dos parentes, obrigando-as a residirem fora de suas terras, a homens e mulheres trabalharem nas fazendas de seus antagonistas como empregadas domésticas, diaristas, caseiros ou prestar serviço de "dias" em períodos de colheita de milho, soja e algodão.

A Associação Remanescente de Quilombo Ribeiro Itambé, possui aproximadamente 400 pessoas, e algumas residências na localidade conhecida como Peba em alusão ao tatupeba que, ao sair de um buraco, fez com que os garimpeiros encontrassem uma grande pedra de diamante na década de 1930, quando a região era explorada pelo garimpo. O quilombo Ribeirão Itambé localiza-se na zona rural a $45 \mathrm{~km}$ de distância da zona urbana da cidade de Chapada dos Guimarães com acesso pelas estradas de terra. Outro nome dado a localidade é Camundá, palavra de origem africana e nome que a geração mais antiga prefere se referir ao lugar. Este quilombo também é conhecido como comunidade Cachoeira Rica, nome do rio que atravessa a localidade na qual residem alguns agregados que possuem relações de amizade e compadrio com os quilombolas e outros moradores considerados "de fora", como o advogado de um grupo de fazendeiros que se dizem "proprietários" das terras do quilombo. 
O quilombo de Cambambi, por sua vez, representado pela Associação Remanescente de Quilombo Morro do Cambambi, se constitui de 14 irmandades: Pingador, Varginha, Cachoeira Bom Jardim, Morro Bom Jardim, Bom Jardim, Pedra Preta, Mata do Cipó, João Carro, Barra de Água-Fria, Biquinha, Água-Fria, Campestre, Estivado e Bocaina do Aguaçú, distante $60 \mathrm{~km}$ da zona urbana do município. As 14 irmandades somam mais de 1.200 indivíduos. ${ }^{4}$ As pessoas do quilombo, como o presidente da associação e principal liderança, Antero Pereira do Nascimento (Seu Teco), Maria Afifia Bezerra (Dona Fifa), Anacleta de Souza de Crisóstomo, Adelino Fernandes da Conceição e Melícia Alves da Conceição, Joana Cezina de Oliveira Martinho (Dona Tuta), Emídio de Souza, Maria Beltrão, Benedito Brás, se identificam como "herdeiros" das terras de seus bisavôs, das antigas irmandades consideradas as mais antigas, algumas com 150 anos de existência. São assertivas em dizer que estavam ali antes dos grandes fazendeiros. Os topônimos dos quilombos, Lagoinha de Cima, Lagoinha de Baixo, Ribeirão Itambé e Cambambi, fazem referência aos rios, córregos e morros, bocainas e buritizais que compõem o território e a paisagem de Chapada dos Guimarães.

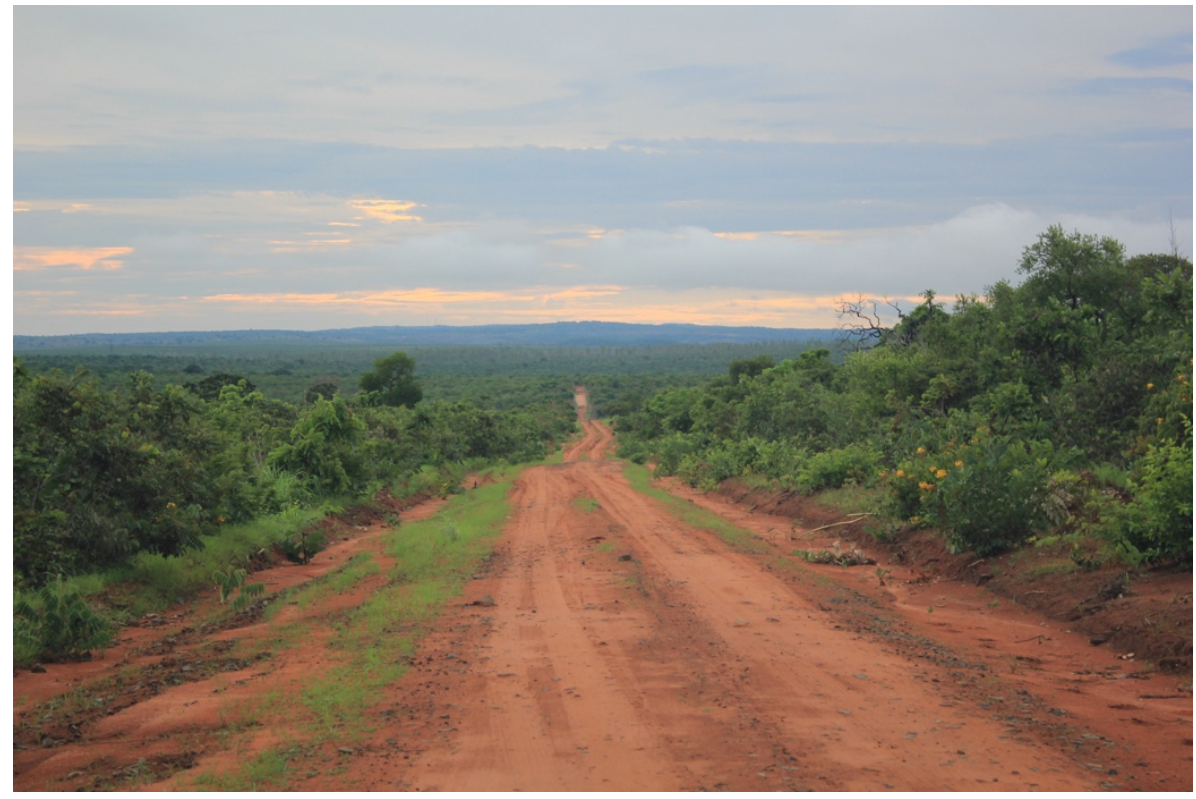

Foto 1: estrada vicinal de acesso aos arraiais Varginha, Pingador, Cachoeira Bom Jardim, Morro Bom Jardim, Bocaina do Aguaçú e todas as outras nove localidades que constituem o Quilombo Morro do Cambambi. Data: 4 de novembro de 2018. Crédito: Sonia R. Lourenço.

\footnotetext{
${ }^{4}$ Não há dados exatos sobre o número de famílias em todas as 14 localidades do grande quilombo Morro do Cambambi porque a pesquisa está em andamento.
} 
Cambambi é um nome de origem africana, da região de Angola, e um dos significados é feiticeiro, personagem constante e presente nas narrativas dos habitantes do quilombo sobre a presença histórica de africanos e africanas considerados poderosos na prática da feitiçaria e da benzeção. Entre um encontro e outro da pesquisa de campo, algumas pessoas são identificadas como feiticeiras ou benzedeiras, pessoas que "sabem usar bem as palavras" durante as rezas para que "tudo dê certo", ou seja, a eficácia da benzeção, do uso de remédios do mato vêm sempre acompanhados de uma reza e do uso cuidadoso das palavras e das substâncias. Fazer com que "tudo dê certo" é um efeito de quem tem domínio sobre a prática. ${ }^{5}$ As etnografias de Félix (2011) e Vieira (2015) mostram que a vida social em diferentes comunidades quilombolas como em Serrinha, localizada no Baixo-Amazonas, município de Oriximiná, no estado do Pará, e na Malhada, situada no Alto Sertão do Caetité, estado da Bahia, respectivamente, são constituídas por práticas de cura como as benzeções que protegem contra as "porcariadas", os "feitiços" e as "coisas ruins".

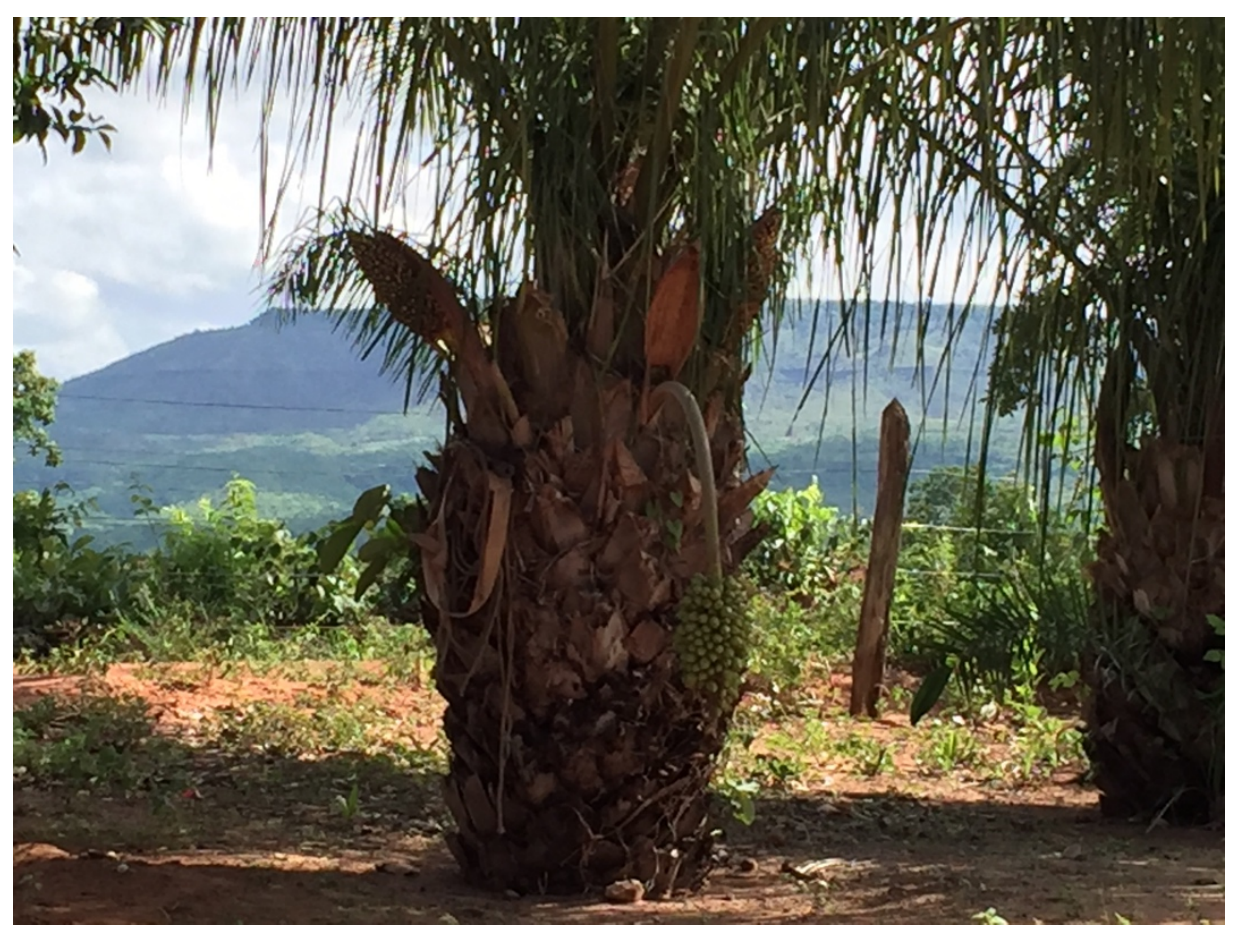

\footnotetext{
5 Nos termos de Stengers (2015, p. 94), "trata-se, ao contrário, de estabelecer da arte do que os gregos chamavam de pharmakon, que se pode traduzir por "droga". O que caracteriza o pharmakon é, a um só tempo, sua eficácia e sua ausência de identidade: ele pode ser, conforme a dosagem e o uso, tanto veneno quanto remédio". O aprendizado das dosagens e a maneira de preparar é análogo à escritura para Jacques Derrida que, segundo a autora, é pharmakon, uma forma de dosagem da loucura" (Stengers, http://www.filoinfo.net/node/54)
} 
Foto 2: ao fundo, o Morro do Cambambi. No primeiro plano, um pé de bacuri (nome científico Platonia insignis), residência de Dona Erenir Nascimento Da Matta e Argermiro de Lima, Comunidade Pingador. Data: 3 de novembro de 2018. Crédito: $\mathrm{xxx}$

Além deste significado, Cambambi é o nome dado ao morro e à associação por ser considerado um lugar mítico, histórico e simbólico de ocupação dos antigos africanos, escravos e quilombolas. É um lugar de referência da memória coletiva como lembram Dona Manoelina e a sua irmã Petronila ao dizerem que "à noite quando crianças, viam de longe, do quintal de suas casas, luzes como tochas de fogo em cima do morro. Mamãe dizia que era boitatá, outras pessoas diziam que eram gente mesmo, muito antiga do quilombo" (19/08/2018). No Morro do Cambambi, há um cemitério no qual se encontram as sepulturas das "famílias de raiz, dos antigos" (Antero Pereira Nascimento).

Cambambi é um morro de formação rochosa de mais de 84 milhões de anos e é considerado uma grande "caixa d'água" que abastece todas as localidades do quilombo. $\mathrm{Na}$ oficina realizada em Bocaina do Aguaçú, identificaram 27 nascentes que irrigam os córregos, rios e cachoeiras da região. É de Cambambi que chega a água potável por "gravidade"6 até as residências das localidades de Pingador, Varginha Morro Bom Jardim, Bom Jardim, Bocaina no Aguaçú e Água-Fria. As outras localidades situadas na beira do lago de Manso como João Carro, Mata do Cipó, Pedra Preta, Campestre e parte de Pingador, sofrem com falta de água potável, obrigando muitas famílias a dependerem do abastecimento de carro-pipa feita pela prefeitura municipal que nem sempre atende de forma regular.

Houve sucessivos eventos de violência que culminaram na expulsão e alagamento de aproximadamente 44 mil hectares de terras do quilombo Morro do Cambambi com a construção e posterior funcionamento da Usina Hidrelétrica de Manso (UHE) pela empresa de Furnas e Eletrobrás, entre 1999 e 2000. A UHE produziu impactos de grandes proporções na vida do quilombo e como consequência o deslocamento de dezenas de famílias para outros lugares, distantes de suas terras de ocupação histórica onde "nasceram e foram criados", e foram obrigadas a viver em terras consideradas por eles como impróprias para o cultivo de roças, outras passaram a viver na beira do lago criado com a UHE de Manso, com água imprópria para o

\footnotetext{
${ }^{6}$ Sistema de abastecimento de água captada do pé das serras chamadas de bocainas. A manutenção do sistema de gravidade é feita pelos próprios quilombolas.
} 
consumo, cheio de piranhas no lugar de piraputanga, piau, pintado e dourado, peixes que eram abundantes no rio Manso, Rio Lagoinha, Rio Acorá e rio Quilombo.

As famílias dos quilombos e da cidade de Chapda dos Guimarães, vivem sob o calor intenso e terras cheias de areia e pedra, impróprias para as hortas e roças. Muitas famílias que tiveram as terras submersas pela UHE, foram assentadas em 10 ou 16 hectares consideradas insuficientes "para gente viver como antigamente com roças de mandioca, milho, feijão, amendoim, criação de animais (porco, galinha, pato, vaca de leite) e cana pra fazer rapadura" (falas de Adelino, Antero e Anacleta).

No processo de desenvolvimento da pesquisa de campo para a elaboração do laudo antropológico, e, portanto, do processo de reconhecimento de direitos, a identidade política de quilombola aparece relacionada a devoção aos santos - São Benedito, São José, São João, Santo Antônio, Nossa Senhora Aparecida, Nossa Senhora da Guia - cultuados durante o ano inteiro. Cada festa de santo mobiliza mais de 300 pessoas que chegam de outras localidades e municípios para apreciar a festa, pagar promessas, visitar as irmandades de santo, reencontrar os parentes e participar do ritual que amalgama comensalidade, devoção, parentesco, dádivas e dívidas, reatualizando a territorialidade e a cosmologia.

O contexto etnográfico aponta uma relação possível entre a territorialidade e os santos por meio da rede de irmandades de parentes e irmandades de santo. A terra, aparece evocada na relação entre terras de santo e terras de uso comum. A primeira noção se refere à cosmologia que inclui as festas de santo, a noção de irmandade religiosa e irmandade de parentes, a segunda se refere à perspectiva histórica do grupo da ocupação da terra de uso comum e à noção de irmandade de santos. Enquanto no quilombo Nossa Senhora do Carmo, localizado no município de São Roque, a "origem comum" é "definida pela descendência direta da Santa, considerada a proprietária de todas as terras e a mãe de todos - gente de uma reza só" (STUCCHI \& FERREIRA, 2014: 93, grifos das autoras), no contexto sociocultural de Cambambi a territorialidade é definida pela vinculação das irmandades com São Benedito, São José, São João, Santo Antônio, Nossa Senhora Aparecida e Nossa Senhora da Guia.

Organizar e oferecer as festas de santo durante o ano inteiro é "encontrar os parentes em vida e não na morte" como ressaltou Fidélis ao ser perguntado por mim sobre o motivo de organizar as festas: "para encontrar os parentes". Fidélis trabalha, temporariamente, para o ICMbio e mora com os pais, Adelino Fernandes da Conceição e Melícia Alves da Conceição, na localidade de Pingador em 2 hectares de terra, 
considerada por eles como "ruim para a roça". Os pais de Fidélis recebem aposentadoria rural, a única fonte de renda do casal. As festas de santo asseguram a continuidade das irmandades e fortalecem os laços socais entre eles.

A experiência cotidiana nas localidades do quilombo Cambambi é tecida pelos contínuos encontros de filhos e netos, genros e noras, primos, cunhados e cunhadas, compadres e comadres, em suma, consanguíneos e afins, nas casas das avós e mães. São as mulheres que recebem, cuidam e realizam os preparativos para as festas, os almoços de sábados e domingos. Há sempre um motivo para encontrar os parentes que chegam de outras localidades, da área urbana de Chapada dos Guimarães, dos bairros periféricos de Cuiabá e Várzea Grande, dos municípios de Planalto da Serra, Rondonópolis, Livramento, onde estão "esparramados".

"Esparramados" é uma categoria nativa falada também no quilombo de Serra da Bocaina, município de Porto Estrela, estado de Mato Grosso (Barros \& Santos, 2016) para se referir ao processo de expulsão a que foram submetidos em sucessivos eventos ao longo do século XX e XXI, a desterritorialização que mobilizou as pessoas originárias dos quilombos a viver em contextos urbanos e a rearranjarem-se em formas de redes interlocais e extralocais que fortalecem o pertencimento aos territórios de ocupação histórica.

A categoria "esparramados" pode ser pensada para além do sentido físico de deslocamento das terras coletivas e ser considerada com um modo possível por meio do qual, os quilombos procuraram reconstruir seus modos de existência. Os quilombos resistem aos processos de exclusão e insistem na retomada de seus territórios, produzindo agenciamentos e linhas de devir que passam pelo meio e não pelo centro do Estado. Nos termos de Deleuze e Guattari (2005: 85-87), “só há sujeito do devir como variável desterritorializado da maioria, e só há termo médium do devir como variável desterrritorializante de uma minoria” (...). “Os devires são minoritários, todo devir é um devir-minoritário".

É em torno da cozinha, das festas de santo e do muxirum que o quilombo produz e percorre por linhas que atravessam os centros de poder, fazendas e instituições para se expandir pelas ruas e bairros da cidade. A casa de quilombo inclui o quintal, a roça, o buritizal e o córregozinho de água fresca. A cozinha opera como uma matriz relacional por onde circulam histórias, contos, causos, devoção, risos, fofocas e políticas. A cozinha situada nos quilombos da zona rural e sertão de Chapada dos Guimarães, se 
encontra nos quintais das famílias desterritorializadas que vivem nas zonas urbanas de Cuiabá e Várzea Grande.

Mas é importante observar que a cozinha quilombola não está para a natureza assim como a roça não está para a cultura se pensarmos nas relações que opõem natureza e cultura, doméstico e público, feminino e masculino. A cozinha é o lugar de encontros de homens, mulheres, jovens e crianças, é o lugar da política e da aliança.

Em cada casa, como na residência de Anacleta, da localidade de Varginha, de Josefa, da localidade de Biquinha, ou de Tuta da localidade de Pingador, a sala é o lugar que abriga o altar dos santos (Foto 3), feitos de estatuetas, flores de crepom, laços, lantejoulas e chita, velas e flores perfumadas. A organização espacial das residências quilombolas têm uma forma singular que divide a primeira parte da casa em dois ou três quartos, a sala com o altar do santo tem a porta aberta para a frente do portão de entrada.

Na residência de Dona Maria Salomé, de 83 anos, da comunidade Cachoeira Bom Jardim, ela explicou que a pessoa festeira herda os assentamentos dos santos dos pais, avós ou tias colaterais. O dono do assentamento do santo tem seus amigos festeiros que atuam como Rei, Rainha, Alferes e Capitão do Mastro, rezadora ou rezador e Capelão, compondo 12 festeiros - os tocadores e cantadores. Salomé herdou a festa do Divino Espírito Santo de seus pais, “Os santos, há mais de 100 anos, eram da minha avó, eles moravam em três barras, na perto do córrego do quilombo. Quando papai morreu, mamãe morreu, mudamos para cá" (Dona Maria Salomé da Silva) ${ }^{7}$. Ao ser interpelada pela pesquisadora, dona Salomé faz um relato do tempo que as festas eram mais abundantes e das práticas do muxirum,

Salomé: "Eu nasci e criei na roça, eu sei contar a vida da roça! O muxirum era pra reunir aquele pessoal pra derrubar ou então roçar, ou carpir. Pra plantar a roça, eu fiz muita farinha, muitas vezes levantava uma hora da madrugada pra bem cedo torrar! Plantava milho, arroz, feijão, cana, tudo que a gente ocupa a gente plantava, quiabo, batata, cará, abóbora, melão, o que nós fazíamos... Moía muita cana, fazia muita farinha, hoje que eu não aguento fazer mais nada, vendia tudo por aqui mesmo, as vezes fazia só pra despesa. $\mathrm{O}$ arroz, o feijão e o milho, tinha vez que levava pra Cuiabá e tinha vez que não dava, porque nós não tocava roça grande era um pedação pra num ficar capoeira né, era um meio alqueire abaixo, uma coisa que a gente aguentava lutar pra não ficar com capoeira! ficar com capoeira!

Antero: A senhora chegou de ir em Cuiabá a pé? Com tropa?

Salomé: "Eu fui muitas vezes, montada a cavalo, de a pé quem que aguenta ?!Teco, oito dias, era cinco dia pra ir e vim né? Assim mesmo saindo madrugada quase meia noite! Nós pousávamos na estrada, parava num lugar de ponto de pouso e armava uma corda dum pau no outro (risos), nós usávamos só a farofa né, a

\footnotetext{
7 Encontro com dona Salomé e seu Antero Pereira - Comunidade Cachoeira Bom Jardim - Cambambi, 22/04/2018. Transcrição: Abenízia Auxiliadora Barros (graduanda em Ciências Sociais, UFMT).
} 
matula, levava caldeirão, arroz, o café e o açúcar! Oh tempo bom! Esse aqui é meu conhecido a muito tempo, Teco, Tico, Jovito, Durvalino, tudo é meu conhecido de muito tempo, nós festávamos na casa dele lá, eles festavam na nossa! Ainda tem os festeiros assentados. O festeiro é a pessoa que tem assento o nome dos festeiros pra fazer a festa, é o adjutório da festa!

Antero: "É o rei, a rainha, o capitão do mastro, o alferes de bandeira, aí você arruma doze festeiros, aqui a senhora tinha senhor divino?

Salomé: "Tinha... Esse quebrou! Aí me deram esse outro! Agora dia vinte ou vinte e dois de maio é a reza dele, todo ano nós rezamos no dia, Dante que tira esse ano! É só mesmo a reza, acabou, tomou café, pronto! Era uma festa boa, duas noites, oh festa boa!

Pesquisadora: E quem que pode continuar a fazer a festa? Se a senhora não fizer mais passa pra quem?

Salomé: Não vai né! Porque o festeiro já é assentado! Que é pro festeiro fazer. É muitos anos, do tempo de minha mãe, de meu pai! Eu nem não tinha nascido, parece que eles tinham dois ou três filhos, tem mais de oitenta anos, já vai pra cem, eles moravam ali no Três Barra ali pra lá de pontinho, lá que eles começaram a festa, daí pra cá toda vida, lá pro monjolo lá perto do JJ, lá todo ano fazia a festa, ai que veio aqui pra cachoeira, ai aqui na cachoeira que não teve mais! Ai papai morreu, mamãe morreu e eu segui fazendo até lá no Zé Gaudêncio, sua mãe era festeira lá, ai mudamos pra cá, aqui foi uns sete anos ai parou, assim... não sei porque que parou! tinha nada de venda não e o que sobrava era um pouquinho pra cada um! Na hora da (palavra inaudível) do altar é que descia o mastro aí assentava outro festeiro, descia o mastro, encostava e ele apodrecia lá! Festa de ano é bonita demais! (...). A terra era boa! Meu Deus do céu! Tudo que se planta fica bom! Agora não planto mais, não aguento nem conversar! Nas festas eu fazia licor de leite, de folha de lima! Oh! Tempo bom!

Pesquisadora: E pra comer nas festas fazia o que?

Salomé: Matava duas reis, panelão de mandioca com carne, panelão de frango frito, tinha linguiça! Frango e leitoa era pro leilão. O povo catava as prendas tudo, e o pau comendo! E o povo dançava, era na sanfona, naquele tempo era sanfona, com tocador bom, jantava, rezava, levantava o mastro e aí era o povo arrematando prenda, comendo e os outros dançando e ia até o sol raiar, tinha vez que não descia o mastro no mesmo dia e ele oito dias de pé, aí não era outra festa mais o povo vinha e bebia bastante! Festa de ano o que ele ganha tudo é dado, tem o botequim que se quer tomar cerveja vai lá e compra, mais o que o santo ganhou pra festa, tudo é dado!

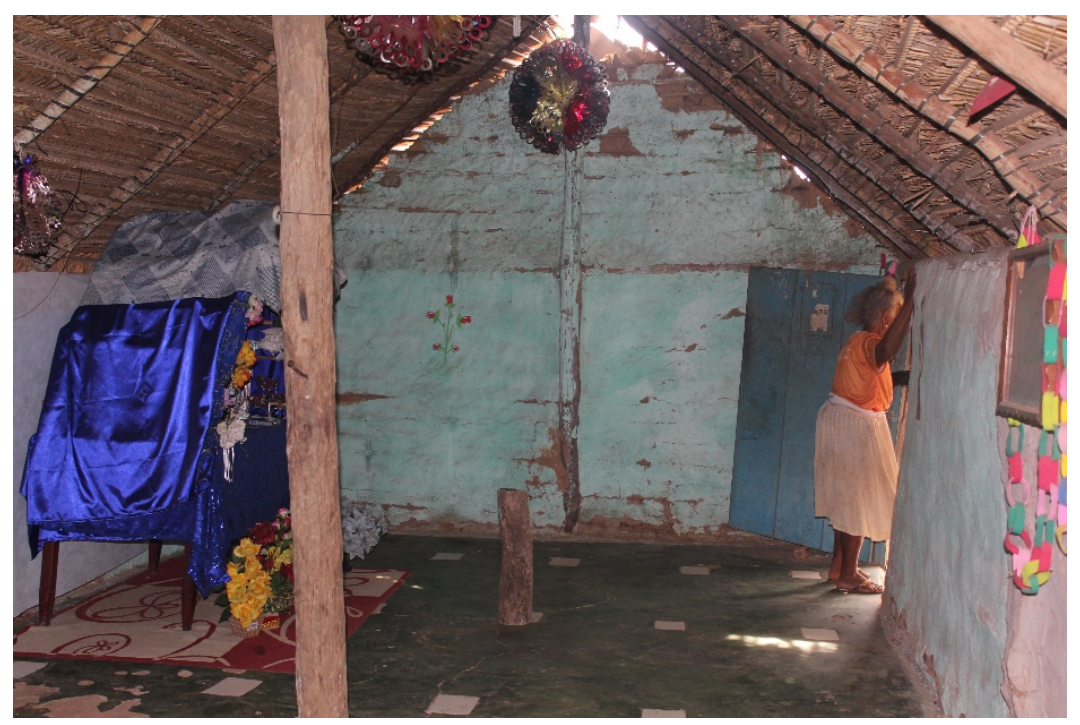


Foto 3: residência de Dona Josefa Sabino dias, salão de entrada com o oratório dos santos, localidade Biquinha, território reivindicado pela comunidade quilombola Morro do Cambambi. Crédito imagem: Sonia R. Lourenço, 10/06/2018.

A segunda parte da casa, abriga o fogão à lenha feito de barro, a pia, os armários para a louça e panelas, os potes e moringas de água, e em algumas delas, a cozinha se torna uma extensão que abriga outro fogão de barro e tacho de cobre para a produção de rapadura, farinha, queijos e doces. A cozinha inclui o girau para destrinchar o porco após o abate, um grande fogão de barro para aquecer grandes panelas de água para a preparação da banha de porco ou para a preparação do cardápio das festas de santo: sarapatel, afogadão (cozido de carne de gado com mandioca e muitos temperos), arroz e farofa de banana-da-terra com toucinho. O churrasco de chão é preparado no dia seguinte pelos homens. No período da manhã que antecede a festa, enquanto um grupo de mulheres e jovens se encontram no ritmo dos preparativos para a festa, os homens preparam o corte da carne bovina, dividindo o quarto traseiro e o quarto dianteiro para o assado, os miúdos para o sarapatel e a cabeça cozida e assada apreciada com uma iguaria pelos adultos.

O corte, a divisão e a distribuição da carne são feitas pelos homens, os responsáveis pelo assado dos cortes principais que serão distribuídos no segundo dia da festa e pelo preparo da cabeça do boi que assa discretamente, separada do churrasco de chão, em outro fogo próximo da cozinha. Se o assado é uma atribuição dos homens, as mulheres, por sua vez, preparam todos os pratos principais dos dois dias de festa: o sarapatel, o cozido de mandioca e carne de gado, chamado de afogadão, o escaldado, o arroz e as saladas.

As festas de santo são realizadas nas casas dos festeiros que devem fornecer toda carne que será servida aos convidados, os acompanhamentos, a bebida, e preparar o cenário para a reza e a instalação do mastro, considerado o momento central do rito. $\mathrm{O}$ oratório é preparado pelas mulheres durante a manhã na sala principal da residência enquanto o mastro é preparado no lado de fora da casa, no quintal próximo dos preparativos culinários. No encontro com Joana Cezina de Oliveira Martinho, conhecida como Dona Tuta, em sua residência na comunidade Pingador, localizada às margens do lago do Manso, ela conta sobre a experiência de "festeira", prerrogativa que herdara de seu pai. O título de "festeira" é uma prerrogativa conferida principalmente às mulheres nos quilombos de Chapada dos Guimarães, mas não exclusivamente a elas. 
As referências às mulheres como "festeiras" são constantes nas comunidades da Biquinha, Mata do Cipó, Água-Fria, Itambé, Lagoinha de Cima, Pingador, Cachoeira Bom Jardim e Varginha. Tuta é o apelido que Joana recebeu de seus pais quando criança porque ela gostava de ficar com uma senhora "bem preta" que era escrava, "É desde criança, quem me deu o apelido foi mamãe com papai, ela contava assim... Tinha uma Tuta bem preta que diz que era escrava e eu deixava de outras pessoas por causa dessa mulher! Aí ela faleceu e eu fiquei sendo Tuta!”

D. Tuta: A festa aqui é o seguinte, ela tem vinte anos de tradição e eu faço essa festa a um pedido de meu pai, que aqui no Pingador tinha festa de Santana e de outros santos, aí por fim todo mundo isolou. Aí meu pai foi e falou assim: "Tuta, aqui nós vivemos muito sofridos porque esquecemos da nossa religião". Então, ele fazia fogueira de São João e mandou eu fazer fogueira de São Pedro, aí todo ano nós fazíamos, reuníamos o povo. Aí ele foi, me chamou e falou assim pra mim: "Este ano você vai marcar uma festa porque eu já estou perto de partir e eu quero deixar isso minha filha, você e Gilberto (seu esposo) enquanto vocês aguentarem vocês vão fazer"! Eu falei pra ele: "Pai, eu não posso, eu não aguento"! Ele falou: "Aguenta minha filha, nós temos amigos"! Aí na reunião da fogueira de São João ele chamou as pessoas pra fogueira de São Pedro na minha casa né! Lá reuniram o pessoal, umas doze pessoas, aí ficou: rei, que dá uma vaca, a rainha que ajuda fazer o doce, o capitão do mastro, o alferes de bandeira, juiz e juíza. Aí faz a festa de dois santos que é São Pedro e Nossa Senhora Aparecida porque aí ajuda você! Assim, ficou doze festeiros. Aí trás o boi que a gente já mata aqui mesmo, aproveita os miúdos e já faz um sarapatel! Faz um afogadão para comer durante a noite! De manhã faz um escaldado, alguma coisa de quebra-torto né! Depois temos o almoço que é o churrasco, de tarde, às três horas tem a costela que é pra merendar! Pra mim o que importa é que eu estou cumprindo um pedido do meu pai e é um evento que vem os parentes, vem gente de todo lado, vem meus alunos que as vezes tem muitos anos que eu não vejo e que as vezes vem, então isso é muito importante pra mim e a gente recebe a bênção também! ${ }^{8}$

A prática de tomar para si o nome do outro como apelido é recorrente nos quilombos de Cambambi e Itambé. Dona Durvalina Rodrigues Rondon, do quilombo Itambé, tomou o nome do falecido esposo, Francisco Rodrigues Rondon, como seu apelido. É dela a prática de nomear as vacas de leite com nomes herdados de sua mãe e de sua avó: Rapadura, Neguinha, Café, Bolachinha, Estrela, Beleza, Delícia e Bonita (nome herdado de sua mãe). Se nascer bezerro "macho" ela não dá um nome porque, segundo ela "o que é de comer, eu não tenho dó não. Faço mocotó, sarapatel, frito as tripas" (Dona Chica, 03/10/2015).

\footnotetext{
${ }^{8}$ Encontro com Joana Cezina de Oliveira Martinho, dia 04/08/2018, comunidade Pingador, Chapada dos Guimarães. Transcrição dos diálogos: Abenizia Auxiliadora Barros, 28/08/2018, pesquisadora do projeto.
} 
O escaldado é o segundo prato servido nas festas de santo que consiste de um cozido de galinha caipira bem temperado com alho, cebola, pimentões, tomate, pimenta-do-reino, farinha de mandioca ou farinha de milho e ovos. Após a farinha de mandioca alcançar a consistência cremosa, acrescenta-se os ovos cozidos inteiros e o cheiro verde, em seguida, os anfitriões servem os convidados.

Quadro 1. Circuito das festas de santo - Quilombos de Chapada dos Guimarães

\begin{tabular}{|c|c|c|c|}
\hline Nome & Festa/Santo & Período & Comunidade \\
\hline Emídio de Souza & $\begin{array}{l}\text { Nossa Senhora da Imaculada } \\
\text { Conceição }\end{array}$ & dezembro & $\begin{array}{l}\text { Cachoeira Bom Jardim } \\
\text { Bocaina do Aguaçú - Quilombo } \\
\text { Morro do Cambambi }\end{array}$ \\
\hline Emídio de Souza & Glorioso Bom Jesus & janeiro & $\begin{array}{l}\text { Cachoeira Bom Jardim } \\
\text { Bocaina do Aguaçú - Quilombo } \\
\text { Morro do Cambambi }\end{array}$ \\
\hline José Geraldo & Glorioso São Gonçalo & janeiro & $\begin{array}{l}\text { Água-Fria - Quilombo Morro } \\
\text { do Cambambi }\end{array}$ \\
\hline Dona Vanildes & Glorioso São Gonçalo & janeiro & Lagoinha de Cima \\
\hline Dona Vanildes & Nossa Senhora da Guia & maio & Lagoinha de Cima \\
\hline Dona Vanildes & Glorioso São Benedito & julho & $\begin{array}{l}\text { Cachoeira Bom Jardim } \\
\text { Bocaina do Aguaçú - Quilombo } \\
\text { Morro do Cambambi }\end{array}$ \\
\hline Dona Antônia & Glorioso Santo Antônio & julho & $\begin{array}{l}\text { Água-Fria - Quilombo Morro } \\
\text { do Cambambi }\end{array}$ \\
\hline $\begin{array}{l}\text { Josefa Sabino } \\
\text { dias }\end{array}$ & Nossa Senhora da Guia & agosto & $\begin{array}{l}\text { Biquinha - Quilombo Morro do } \\
\text { Cambambi }\end{array}$ \\
\hline $\begin{array}{l}\text { Josefa Sabino } \\
\text { dias }\end{array}$ & São Benedito & julho/agosto & $\begin{array}{l}\text { Biquinha - Quilombo Morro do } \\
\text { Cambambi }\end{array}$ \\
\hline $\begin{array}{l}\text { Josefa Sabino } \\
\text { dias }\end{array}$ & Nossa Senhora do Bom Despacho & setembro & $\begin{array}{l}\text { Biquinha - Quilombo Morro do } \\
\text { Cambambi }\end{array}$ \\
\hline Dona Martinha & Nossa Senhora Aparecida & agosto & $\begin{array}{l}\text { Mata do Cipó - Quilombo } \\
\text { Morro do Cambambi }\end{array}$ \\
\hline Dona Martinha & Santa Luzia & agosto & $\begin{array}{l}\text { Mata do Cipó - Quilombo } \\
\text { Morro do Cambambi }\end{array}$ \\
\hline Dona Anacleta & Glorioso Santo Antônio & julho & $\begin{array}{l}\text { Varginha - Quilombo Morro do } \\
\text { Cambambi }\end{array}$ \\
\hline Dona Anacleta & Glorioso São Benedito & julho & $\begin{array}{l}\text { Varginha - Quilombo Morro do } \\
\text { Cambambi }\end{array}$ \\
\hline
\end{tabular}


Encontros e Comensalidade nos Quilombos: O Devir Quilombo

\begin{tabular}{|l|l|l|l|}
\hline Dona Tuta & Glorioso São João & agosto & $\begin{array}{l}\text { Pingador - Quilombo Morro do } \\
\text { Cambambi }\end{array}$ \\
\hline Dona Tuta & Glorioso São Pedro & agosto & $\begin{array}{l}\text { Pingador - Quilombo Morro do } \\
\text { Cambambi }\end{array}$ \\
\hline Dona Marcelina & $\begin{array}{l}\text { São Benedito, Santo Antônio e } \\
\text { Nossa Senhora Aparecida }\end{array}$ & $\begin{array}{l}\text { agão Carro - Quilombo Morro } \\
\text { do Cambambi }\end{array}$ \\
\hline
\end{tabular}

Em todos os quintais quilombolas, encontra-se a horta, uma continuidade da cozinha, situada entre as linhas que dividem a roça e a pequena mata ou buritizal, há uma variedade de temperos como salsinha, alho-porro, cebolinha, coentro, pés de pimenta, quiabo, abóboras, pomar de frutas como graviola, mamoeiro, banana, laranjeira, limoeiro, seriguela, carambola, cana, babaçu, bocaiúva, buriti, bacuri , tamarindo, entre outras frutas do cerrado. As mulheres são agentes diretas das hortas e jardins, as responsáveis pelo cultivo das plantas medicinais, comestíveis e ornamentais, transformando o entorno das casas em ricos jardins, reaproveitado velhos carrinhos de mão, tachos, panelas, pneus, latas e garrafas em suportes e recipiente para cebolinhas, salsinhas, orquídeas, rosas, entre muitas outras plantas e flores.

Nas linhas que separam as hortas das roças, galinhas, patos e pintinhos circulam soltos pelos quintais, enquanto os porcos se encontram nos chiqueiros entre o quintal e o início das roças de mandioca. Muitas famílias criam suínos para o consumo próprio. São criações de 05 a 15 unidades de suínos alimentados com os produtos da roça ou parcialmente com ração. A criação de suínos garante a produção de banha, toucinho e carne, divididas entre as famílias que compõe a irmandade.

As roças, os pomares e os quintais, fornecem os principais alimentos do sistema alimentar e culinário dos quilombos. $\mathrm{O}$ arroz e o feijão, são comprados nos mercados da cidade. A fonte de proteínas é retirada da carne do porco, da galinha caipira, galinha d'angola, patos, marrecos e da carne de caça (porco queixada, caititu, veado mateiro e paca), os carboidratos são oriundos da mandioca, arroz e milho do qual preparam a pamonha doce e salgada. Do cará preparam o doce de leite e pão, duas receitas criadas por Dona Vanilde Oliveira Valentim do quilombo Lagoinha de Cima. É dela também a receita de geleia de tomate doce.

Antes da apropriação do território tradicional por seus antagonistas, homens e mulheres pescavam nos rios Lagoinha, Quilombo, Acorá, Rio da Casca e Cachoeira Rica, rios piscosos de pintado, piraputanga, pacu e dourado. A pesca foi uma importante 
fonte de alimentos para as comunidades quilombolas até meados dos anos de 1970 e 1980 quando tiveram a invasão dos territórios com a grilagem de terras e a construção da Usina de Manso por Furnas e Eletrobrás em 1999 e 2000, alterando os cursos das águas de todo a região de Chapada dos Guimarães.

As roças no território quilombola Morro do Cambambi não ultrapassam mais do que 4 hectares por família, algumas chegam a cultivar pequenas roças de 2 hectares de mandioca (Manihot esculenta Crantz). Em comparação, outros municípios do estado de Mato Grosso, a produção de mandioca soma até 19.093 hectares de área colhida, com 277.077 toneladas e rendimento de 14,51 t/há, segundo os dados da produção agrícola municipal do IBGE de 2017. ${ }^{9}$ A produção das roças quilombolas não foram consideradas nos dados do IBGE, apenas aquelas produzidas por proprietários de fazendas. No município de Chapada dos Guimarães, a produção de mandioca é baixa considerando que a produção agrícola é majoritariamente de monoculturas de algodão herbáceo, milho e soja nas grades fazendas.

\begin{tabular}{|c|c|c|c|c|c|}
\hline \multicolumn{6}{|c|}{ Variável - Área plantada (Hectares) } \\
\hline \multirow[b]{3}{*}{ Município } & \multicolumn{5}{|c|}{ Ano x Produto das lavouras temporárias } \\
\hline & \multicolumn{5}{|c|}{2017} \\
\hline & Total & $\begin{array}{l}\text { Algodão herbáceo (em } \\
\text { caroço) }\end{array}$ & Mandioca & $\begin{array}{l}\text { Milho (em } \\
\text { grão) }\end{array}$ & \begin{tabular}{|l}
$\begin{array}{l}\text { Soja (em } \\
\text { grão) }\end{array}$ \\
\end{tabular} \\
\hline $\begin{array}{l}\text { Chapada dos } \\
\text { Guimarães (MT) }\end{array}$ & 24798 & 6146 & 600 & 4500 & 13500 \\
\hline
\end{tabular}

Fonte: IBGE - Produção Agrícola Municipal - 2019

A Embrapa realizou uma pesquisa na região conhecida como Baixada Cuiabana, ao norte do Pantanal, que abrange 14 municípios - Acorizal, Barão de Melgaço Campo Verde, Chapada dos Guimarães, Cuiabá, Jangada, Nobres, Nossa Senhora do Livramento, Nova Brasilândia, Poconé, Rosário Oeste, Santo Antônio do Leverger, Várzea Grande e Planalto da Serra-, para identificar as principais variedades de mandioca produzidas por diversas comunidades tradicionais (quilombolas, pantaneiros e ribeirinhos):

99 Embrapa - Fonte: IBGE - Produção Agrícola Municipal, 2017. http://www.cnpmf.embrapa.br/Base_de_Dados/index_pdf/dados/brasil/mandioca/b1_mandioca. pdf 
"No total, foram citadas 24 variedades, sendo nove mencionadas como usadas exclusivamente para indústria, sete para mandioca de mesa e oito para ambos os usos. As variedades Igarapé Vermelha, Broto Branco, Brava, Seringueira, Galhadeira, Olho Junto e Espeto foram citadas como variedades para a fabricação de farinha, o que corresponde a $39 \%$ do total de variedades citadas. As variedades: Sopão, Uva, Mansa, Broto Roxo, Palmeira e Branquinha do Sul foram citadas para comércio ou mesa, representando $36 \%$ das variedades citadas. Já as variedades: Liberata, Juriti, Cacau, Branquinha, Amarra boi, Pão, Osso, Manteiga e amarelona, foram citadas com dupla aptidão e representando $25 \%$ das variedades. A variedade Liberata foi identificada como a mais cultivada, presente em todos os municípios da BC. As variedades crioulas ocupam $100 \%$ das roças de mandioca da $\mathrm{BC}$, sendo, portanto, a base para a produção das farinhas artesanais. Há preferência pelas variedades de indústria, seguida daquelas com dupla aptidão". ${ }^{10}$

A produção de mandioca se comparada com a produção de algodão, milho e soja do agronegócio, é muito pequena, embora constitua uma raiz central no sistema alimentar das comunidades quilombolas do estado de Mato Grosso. Nos quilombos, o cultivo da mandioca é feito em duas estações: preparam a terra e plantam as ramas no final da estação seca que compreende o mês de agosto até o período das primeiras chuvas de outubro e colhem as primeiras raízes na estação chuvosa, de janeiro a março do ano seguinte.

O cultivo de mandioca liberata ou Camanducaia nas terras disponíveis é insuficiente para manter uma produção que possa aumentar a renda e garantir a alimentação cotidiana de todos. Quando lembram dos tempos antigos, os lampejos da memória narram uma vida plena de abundância nas terras de uso comum. A conceitualização de terras de uso comum é corriqueira nas falas, narrativas, lembranças e discursos dos quilombolas para se referirem ao modo de existência próprio em que a terra é um bem coletivo na qual as cercas não significam o símbolo da propriedade privada, mas a proteção das roças contra o caititu e o porco-queixada que se alimentam de raízes e tubérculos (inhame e batata-doce).

No encontro com dona Juvenita dias da Cruz, seu esposo Adalberto Pinto da Cruz e sua irmã dona Durvalina Dias Rodrigues (conhecida como dona Chica) ${ }^{11}$, seu Adalberto conta como produz a farinha de mandioca enquanto mostra o forno artesanal de torrar farinha, ao lado da horta:

\footnotetext{
${ }^{10}$ https://www.embrapa.br/busca-de-publicacoes/-/publicacao/1105877/principais-variedades-demandioca-utilizadas-em-treze-municipios-do-mato-grosso-regiao-da-baixada-cuiabana

${ }^{11}$ Encontro Juvenita dias da Cruz e Adalberto Pinto da Cruz, Durvalina Dias Rodrigues, irmã de Juvenita, em sua residência. Quilombo Ribeirão Itambé, 19/09/2015. Transcrição: Abenizia Auxiliadora Barros, 02/07/2018.
} 
Adalberto: "A farinha é o seguinte, a senhora arranca a casca da mandioca, aí rala ela, imprensa ali, como está ali e aí depois de imprensada, côa e vem pro forno pra torrar Hoje vi beirar um saco, um saco de farinha dá quarenta e cinco quilos!

Pesquisadora: Essa farinha é feita pra vocês comerem ou pra vender também?

Adalberto: Pra consumo é pouco né! É que a pessoal encomenda muito e aí nós pegamos pra fazer e já tiramos o do nosso consumo, a gente não faz todo dia, é conforme as encomendas, conforme eles encomendam a gente vai fazendo! Porque os mercados, eles estão muito exigentes pra senhora vender o saco de farinha, eles querem tudo embalado, aí a gente vende assim particular dos mercados, pra outras pessoas! Alí, bem ali na frente, essa é a mandioca liberata, sempre que nós plantamos agora é só a liberata. Outras qualidades eu não plantei aqui!

Pesquisadora: Aprendeu fazer farinha com quem?

Adalberto: Ah, eu aprendi com meu pai, o nome dele era Guilherme, ele morreu em setenta e nove! Ele tocava lavoura grande, aí tinha os filhos, aí ele fazia farinhada e todo mundo ajudava, as criançadas ajudavam! Então, a gente cresceu sabendo!

Além da mandioca, cultivam abóbora, cará, batata-doce, rúcula, alface, cebolinha, pimenta, coentro e cuidam dos pomares composto de frondosas árvores de caju, seriguela, laranja, limão, jenipapo, jacalima, goiaba, pitanga, tamarindo, buriti e mamão. Destas frutas que as mulheres fazem o furrundu, doce de que consiste de mamão verde, rapadura, gengibre, cravo e canela. Após ralar o mamão, vai ao fogo com todos os ingredientes de uma só vez para cozinhar em fogo brando até ficar com consistência adequada. A rapadura é feita com babaçu que é encontrado em abundância no cerrado, polpa e doce de buriti. Dona Salomé narrou um momento de sua experiência no tempo das terras de uso comum quando "a vida era mais farta":

"Da vida na roça eu lembro, do muxirum, tinha milho, feijão, arroz, cana-de-açúcar, cará, quiabo, abóbora, fazia muita farinha, vendia pra fora, fazia rapadura. Coisa que a gente aguentava fazer, ia montada a cavalo até a serra abaixo, eram cinco dias para ir e mais cinco dias para voltar. Carregava matula (farofa), café e açúcar para a viagem. Era um tempo bom”.

O tempo da "vida farta" vivida nas terras de uso comum contrasta com o tempo da violência a que foram expulsos de suas terras por fazendeiros que chegavam "de fora" e no final dos anos 1990, foram desterritorializados com a construção da Usina de Manso. Seu Adelino Fernandes da Conceição e dona Melícia Alves da Conceição, relembram esse período,

Adelino: "Antes, a setenta a oitenta anos as áreas que existiam as pessoas eram analfabeto, não tinham cultura e as pessoas vinham de fora e chegavam já chamando a gente de compadre, de comadre e essas coisas assim pra aproximar, e assim os avós da gente, o pai da gente, os tios faziam qualquer... O povo mato-grossense e principalmente nós sertanejos nós temos muita vontade de conhecer as pessoas e por isso eles aproxima mais da gente e os pensamentos da gente às vezes não é aquilo ali, mas eles aproveitam dessa boa chegada e acaba convencendo a gente, que a cultura da 
gente é completamente diferente... E a gente quer agradar com o quase nada que a gente colhe, com a simplicidade da gente e com isso eles aproveitam das pessoas, por aí (silêncio). Foi por onde começou que nós ficamos no escanteio, sem nada...

Pesquisadora: Com essa intenção o que eles faziam? Como era a troca?

Adelino: O sistema deles... Eles vinham de lá com um pão de guaraná às vezes um pacote de café, às vezes até uma roupinha usada dos filhos deles pra dar pro filho da gente, fumo e assim sucessivamente eles vinham convencendo a gente. Não, mas ele está ajudando a gente, está trazendo... Às vezes na hora de pagar os impostos que vinha...Eles conseguiam fazer o seguinte: "não, deixa esse imposto que eu vou pagar pro compadre", pegava o documento, ia lá no INCRA, no Estado e começava fazer os pagamentos, as vezes a esposa lembrava e falava: "Mas você está deixando fulano pagar

lá?" E o marido falava "não, o compadre está pagando pra nós, ele é gente boa!" O documento é o ITR, e aí ele acabava pegando todos os dados da gente e colocava lá noutro documento e acabava que a gente ficava com medo de não conseguir pagar os impostos e ele falava: "não compadre, eu compro e vou pagando lá e vocês podem continuar fazendo a roça que vocês precisam, criando uma vaquinha, um porco". Aí a gente aceitou aquilo ali e de repente a gente fazia uma roça lá no local, aí eles traziam um gado e colocavam dentro da roça da gente, o gado comia a planta que a gente tinha plantado. E assim, sucessivamente, eles iam destruindo a gente, nós fomos ludibriados por eles durante muitos anos. E depois que eles tomam posse dessa situação eles começam a ameaçar! Foi muito tempo de ameaças que eles faziam pra gente, diziam: "não, vocês vão ter que mudar daqui, porque aqui não é mais seu, é meu, você não pode fazer essa casa assim desse jeito", mudando todo o pensamento da gente! Desde o tempo de nossos avós é que nós vimos sofrendo esse tipo de desgaste"!

Melícia: "Tenho saudade de que a gente lavava roupa lá no córrego, luz não tinha mesmo e ele comprava querosene e nós tinha roça ali no Bom Jardim (outra localidade do quilombo), era saudável porque nós juntávamos as vizinhas com as crianças e nós fazíamos farinhada no ralo, os homens tinham outro serviço e nós fazíamos farinha, ia a tarde eles ia lá pescavam peixe ai nós fazíamos a janta! Passava o dia lá e tinha as meninas aqui, eu levava Fidélis (seu filho) e mais duas crianças mais pequenas, aí ficavam mais três aí, duas ia pra escola e a outra ficava! Moía cana, fazia rapadura, fazia melado. As crianças pegavam melado pra comer. Quando nós íamos ver, estava açucarado aí nós tomávamos café com açúcar do melado que virou! Aí vinha bastante gente pra ver esse osso lá do Cambambi né! Nós fazíamos o café e dava pra eles e eles falavam: "hum, mas isso aqui é gostoso"!

Adelino: "A gente ainda planta mandioca, abóbora, faz uma horta, planta um milho, na horta a gente planta uma rúcula, alface, cenoura, cebolinha, planta banana também, no pomar tem manga, laranja, jaca, lima, pocã, caju, a mandioca a gente consegue colher de caminhão de quatro a cinco tonelada por ano, mais isso ai é toda nossa família que está aqui e alguns anos que da isso! Tem o caminhão que vem e compra e leva pra Cuiabá e vende na feira! Tem que plantar a qualidade de mandioca que os feirantes gostam, tem a liberata e agora apareceu a camanducaia que é muito usada em Santo Antônio do Leverger! Nós já plantamos ela aqui só que não é boa igual a liberata! A diferença é que a liberata colhe com um ano e a camanducaia com seis meses! A gente faz muxirum pra plantar e pra limpar também e é sempre os parentescos! Muxirum é troca de mão de obra! A roça é pequena e é na base de um hectare e a gente usa a enxada! A gente planta junto, a gente o ajuda e quando precisa pra comer ou pra servir o vizinho a gente pega dele! A gente costuma fazer o plantio na lua minguante que é depois da cheia, planta na minguante e limpa na minguante 
que é com trinta dias pra limpar! Logo que a mandioca nasce já precisa está capinando, colhe em junho, julho, faz a farinha pra despesa!"12

A narrativa do casal e de outros quilombolas, falam de processos de violência e do modo como foram expropriados de suas terras ao receberem porções de guaraná, fumo e açúcar "em troca de terras", impostas por "gente de fora", homens vindos de São Paulo, Bahia e Paraná que se tornaram com a apropriação das terras destes coletivos negros, "grandes proprietários rurais", os agentes do agronegócio no centro-oeste brasileiro. Anna Tsing (2015: 186), mostra como o cultivo de grãos propiciou o atrelamento das monoculturas de cana-de-açúcar, milho, soja e trigo à emergência, ascensão e centralização do regime estatal, "os Estados promoveram a agricultura em suas insígnias e exércitos. Algumas vezes outras formas de subsistência foram criminalizadas: apenas os foras da lei recusariam a dádiva da fertilidade estatal". Assim, o Estado fomentou a agricultura intensiva de cereais, estabilizou e legislou para garantir a propriedade privada e a herança entre as oligarquias rurais nas Américas.

\section{Os quilombos $n a$ cidade}

Na residência das irmãs Manoelina da Silva Fernandes, Clarice Alves da Silva Pedroso, Petronila da Silva Santos e Maria da Silva Alves, localizada no bairro Pedregal, na cidade de Cuiabá, realizam com regularidade, encontros com os parentes que somam mais de 100 pessoas que se auto-identificam como quilombolas do Ribeirão Itambé. ${ }^{13} \mathrm{O}$ quintal para esta família é um microcosmo do quilombo. Nele há cantinhos com os temperos, plantas, árvores frondosas e frutas como mamão e pitanga, bancos de madeira, fogão de barro, um cenário que atualiza a memória coletiva de quando viviam em suas terras.

A comida que se põe à mesa é feita de memórias e afetos, servidos junto com a farofa de banana-da-terra, ventrecha de pacu (costelas em postas feitas com farinha de rosca), arroz, feijão e mojica de pintado. Esta última é uma das comidas mais conhecidas em todo o estado de Mato Grosso. A palavra mojica se refere a língua do povo indígena Boé-bororo que alude ao modo de comer o peixe pintado cozido com

${ }^{12}$ Encontro na casa de Adelino e Melícia, 04 de agosto de 2018, comunidade Pingador, Quilombo Morro do Cambambi. Transcrição em 12/09/2018 - Abenízia Auxiliadora Barros (graduanda em Ciências Sociais, FMT).

${ }^{13}$ Encontro realizado no dia 19 de agosto de 2018 com a presença da equipe de pesquisa. 
mandioca. Trata-se de um cozido de pintado com mandioca, pimenta, alho e cebola, coentro e tomates, servido como prato principal. Em torno da mesa, a geração de mulheres mais velhas às mais novas, atualizam os nomes de parentes que já faleceram, contam sobre o nascimento de sobrinhos, filhos e netos e manifestam o desejo de retorno ao território tradicional.

Não há encontro de parentes que não seja um encontro de comensalidade e preparativos para o próximo encontro. Qualquer motivo é suficiente para agendar um novo encontro, pode ser um batizado, um aniversário e as festas de santo para quem é católico. As irmãs Manoelina da Silva Fernandes, Clarice Alves da Silva Pedroso e Maria da Silva Alves, se dizem evangélicas, mas não deixaram de praticar os encontros regados de comida abundante e risos provocados com as narrativas de causos e aventuras da infância no quilombo.

As comunidades rurais, quilombolas, campesinos e povos indígenas, na condição de grupos minoritários, e, portanto, em seu devir, buscaram resistir ao confinamento desta política da maximização de terras e de pessoas. Os quilombos procuraram refazer seus modos de vida nos termos dos "territórios existenciais", conceito formulado por Guattari, (2008). "Territórios existenciais" são "universos de referências, cognitivos, afectivos, estéticos" nos quais há fluxos contínuos e acontecimentos cujas intensidades como as feitiçarias e as benzeções, as festas e a comensalidade nas zonas rurais, intersecionadas pelo agronegócio ou na cidade, atravessadas pelos forças "modernas" da economia capitalista, dizem mais sobre os processos de subjetivação destes coletivos e de sua forma de "apreensão do mundo".

$\mathrm{Na}$ zona rural para driblar a lógica do trabalho individualista e dependente dos patrões, as comunidades quilombolas praticam até hoje o muxirum. A troca de dias está assentada na lógica da reciprocidade, quando alguém retribui um trabalho recebido em suas roças, paga retribuindo com dias de trabalho. Ou seja, implica a retribuição equivalente do beneficiário, que neste caso é considerado um devedor, moralmente comprometido com o outro. A troca sempre implica que alguém está em dívida com outro. Segundo a formulação de Marcel Mauss (2003: 192), as relações sociais são caracterizadas por relações de troca, algumas mais simétricas e horizontais, e outras mais assimétricas e hierarquizadas. $\mathrm{O}$ aspecto central dessas relações é o aspecto criador das dádivas ao ensejar, por meio do muxirum, sociabilidades, comunicação e trocas 
materiais entre as famílias, entre os "de dentro" e os "de fora", e trocas espirituais entre os festeiros e os santos.

Bandeira (1988: 159) identificou o muxirum nas comunidades negras de Vila Bela da Santíssima Trindade como a forma de cooperação recíproca entre parentes da mesma parentela. Um dos interlocutores da pesquisa explicou que o muxirum consistia na cooperação mútua, "todos iam lá fazê o muxirum. Comida ele dava e aí depois fazia aquela festa, aquela alegria. No roçado também fazia muxurim. Já quase acabô". A prática do muxirum vem marcada pela sucessão das festas de santo e não está atrelada pelo aspecto virtualmente contratual do trabalho coletivo ou da troca individual de serviço. O que atravessa as duas práticas, a troca de dias e o muxirum é a rede de parentesco como fonte de cooperação entre os filhos, filhas, irmãos, irmãs, primas e primos, cunhados, compadres e comadres. Todos envolvidos em um sistema de compensações, trocas e retribuições. A descrição do muxirum pelos quilombolas aponta como sendo uma categoria central na economia e na política local.

O quilombo não se limita apenas aos territórios de ocupação histórica e tradicional. A forma que as famílias quilombolas encontraram de rearranjar a existência do quilombo é organizar encontros com os parentes na cidade, longe da terra de seus ancestrais de onde foram expulsas nas décadas de 1970 e 1980 . O que se pode observar deste encontro? Refazem e reatualizam o quilombo nos encontros em torno da cozinha e da comida. A comensalidade produz o parentesco e reatualiza a memória coletiva de quando viviam nas terras de uso comum.

Na contramão do agronegócio, os quilombos insistem em se reterritorializar ao ser, parafraseando Goldman sobre o "devir negro", "capaz de construir novos territórios existenciais onde se reterritorializar de forma criativa. O devir, assim, é o que nos arranca não apenas de nós mesmos, mas de toda identidade substancial possível" (Goldman, 2016:12 apud CRUZ, 2016).

\section{REFERÊNCIAS}

AUGÉ, Marc. Os domínios do parentesco. Filiação, aliança matrimonial, residência. Lisboa, Edições 70, 1975.

BANAL, Alberto \& FORTES, Maria Ester P. (orgs.). Quilombos da Paraíba. João Pessoa: Imprell Gráfica e Editora, 2013. 
BANDEIRA, Maria de Lourdes. Território Negro em Espaço Branco. Estudo antropológico de Vila Bela. São Paulo: Ed. Brasiliense, 1988.

BRASIL. Censo Demográfico 2010. Características da população e dos domicílios Instituto Brasileiro de Geografia e Estatística - IBGE. Ministério do Planejamento, Orçamento e Gestão.

CARSTEN, Janet. A matéria do parentesco. Revista de Antropologia da UFSCar. R@U, 6(2), jul./dez. 2014: 103-118.

CARMO, D. A.; CARMO, A. P. B.; PIRES, J. M. B.; OLIVEIRA, J. L. M. Comportamento ambiental e toxidade dos herbicidas atrazina e simazina. AmbiAgua,Taubaté, v. 8, n. 1, p. 133-143, 2013

GOLDMAN, Marcio. "Prefácio" in: SILVA, Ana Claudia Cruz da. Devir Negro. Uma etnografia de encontros e movimentos afroculturais. Rio de Janeiro, Papeis Selvagens, 2016.

CUNHA, Manuela Carneiro. "Cultura' e cultura: conhecimentos tradicionais e direitos intelectuais". In: . Cultura com aspas. São Paulo: Cosac \& Naify.pp. 311-373.

DELEUZE, Gilles \& GUATTARI, F. "Devir-Intenso, Devir-Animal, DevirImperceptível"in: Mil Platôs. Capitalismo e Esquizofrenia. (Tradução de Suely Rolnik). Vol. 4. SP: Ed. 34, 2005.

FÉLIX, Camila Corrêa. "Eles são cristãos como nós". Humanos e encantados numa comunidade negra amazônica Dissertação de Mestrado. UFRJ, Programa de PósGraduação em Antropologia e Sociologia, 2011.

GUATTARI, Félix. Caosmose. Um novo paradigma estético. São Paulo: Ed. 34, 2008. FERREIRA DA SILVA, Nayara Marcielly. Relatório Final Iniciação Científica (PIBICCNPq) - Projeto de pesquisa Cosmopolíticas, territórios, memórias e performances de comunidades negras de Chapada dos Guimarães-MT, Cuiabá, UFMT, 2016.

GOW, Peter. "Da Etnografia à História: 'Introdução' e 'Conclusão' de Ofmixedblood: kinshipandhistory in Peruvian Amazônia", Cadernos de Campo 14/15, pp. 197-226. 2006 [1991].

GOW, Peter. Of Mixed Blood: Kinship and History in Peruvian Amazonia. Oxford Studies in Social and Cultural Anthropology. Oxford: Oxford University Press, 1991.

HARTUNG, Miriam. Saberes reversos ou o difícil diálogo entre saberes tradicionais e poderes estatais in: Antropologia em primeira mão/Programa de Pós-Graduação em Antropologia Social, Universidade Federal de Santa Catarina, Florianópolis, v. 115, 2009.

Muito além do céu: Escravidão e estratégias de liberdade no Paraná do século XIX, Topoi, v. 6, n. 10, (jan-jun. 2005), pp. 143-191. 
. Parentesco, Casamento e Terra em um grupo rural de negros em Santa Catarina in: LEITE, Ilka Boaventura (org.). Negros no Sul do Brasil. Invisibilidade e Territorialidade. Florianópolis: Letras Contemporâneas, 1996, pp. 105-130.

LANNA, Marcos P. D. A dádiva divina: troca e patronagem no nordeste brasileiro. Campinas: Editora da Unicamp, 1995.

LEITE, Ilka Boaventura. Os quilombos no Brasil: questões conceituais e normativas, Revista Etnográfica, v. 4, n. 2, (2000), p. 333.

O legado do testamento: a Comunidade de Casca em perícia. Porto Algre: Ed. Da UFRGS; Florianópolis? NUER/UFSC, 2004.

O projeto político quilombola: desafios, conquistas e impasses atuais, Revista Estudos Feministas, Florianópolis, v. 16, n. 3, (2008), p. 965-977.

LÉVI-STRAUSS, Claude. "Raça e História" in Antropologia estrutural dois. Rio de Janeiro: Tempo Brasileiro, 1993.

LÉVI-STRAUSS, Claude. As Estruturas Elementares de Parentesco. Petrópolis: Vozes, 1993.

LITTLE, Paul. Territórios sociais e povos tradicionais no Brasil: por uma antropologia da territorialidade. Série Antropologia 322. Programa de Pós-Graduação em Antropologia Social, Brasília, 2002. pp.1-32.

MACÊDO, Ulla. $A$ “dona do corpo”: um olhar sobre a reprodução entre os Tupinambá da Serra-BA. Dissertação de mestrado. Bahia: UFBA, 2007.

MACHADO, Juliana Salles. Lugares de gente: Mulheres, plantas e redes de troca no delta amazônico. Tese (Doutorado em Antropologia Social) - Museu Nacional - UFRJ. Rio de Janeiro, 2012.

MELLO, Marcelo Moura. Reminiscências dos Quilombos. Territórios da memória em uma comunidade negra rural. São Paulo: Ed. Terceiro Nome, 2012.

MESQUITA, José. Grandeza e Decadência de Serra-Acima. Cuiabá Revista do Instituto Histórico e Geográfico de Mato Grosso Anos XII e XIV, números XXVII a XXVIII 1931 e 1932.

MAUSS, Marcel. Sociologia e antropologia. São Paulo: Cosac \& Naify, 2003.

MÜLlER, Cíntia Beatriz. Direitos Étnicos e Territorialização. Dimensões da territorialidade em uma comunidade gaúcha. Porto Alegre: Ed. UFRGS, 2011.

SAHLINS, Marshall. What Kinship Is and Is Not. Chicago and London: The University of Chicago Press, 2013. 
SEEGER, A. DA MATTA, R. \& VIVEIROS DE CASTRO, E. B. "A construção da pessoa nas sociedades indígenas brasileiras", in Oliveira Filho, J. P., org., Sociedades indígenas \& indigenismo no Brasil. Rio de Janeiro: UFRJ/Marco Zero, 1987, p. 11-29.

STENGERS, Isabelle. No tempo das catástrofes. Resistir à barbárie que se aproxima. São Paulo: Cosac 7 Naify, 2015.

STENGERS, Isabelle. Reativar o animismo. Caderno de Leituras n. 62. Tradução Jamille Pinheiro Dias. Chão da Feira, 2014.

TSING, Anna. Margens Indomáveis: Cogumelos Como Espécies Companheiras. Ilha. v. 17, n. 1, p. 177-201, jan./jul. 2015.

Recebido 08/08/2019

Aprovado 11/12/2019 